\title{
Napenergia használata villamosáram termelésre egy családi házon vizsgálva
}

\author{
Á. KovÁcs1, T. JENEI2 \\ Debreceni Egyetem Műszaki Kar, Műszaki Menedzsment és Vállalkozási Tanszék, kovacs.agota94@gmail.com \\ Debreceni Egyetem Műszaki Kar, Műszaki Menedzsment és Vállalkozási Tanszék, jeneit@eng.unideb.hu
}

Absztrakt. A tanulmány első részében SWOT elemzés segítségével bemutatjuk a napenergia és a földgáz energiatermelésben betöltött szerepének erősségeit, gyengeségeit, lehetőségeit és veszélyeit. A második felében egy családi ház napelemes beruházásának megtérülését elemezzük.

Abstract. In this paper we compare the naturalgas and solarenergy utilizatio nwith the help of SWOT analisys. Than we are presenting the solarpower utilization devices and system installation in economic point of view. And two payback calculation method is demonstrated on a family house.

\section{Bevezetés}

Életünk egyik legmeghatározóbb energiája a villamos energia. A legtöbb háztartásban található elektromos áram, amely megkönnyebbíti a mindennapjainkat. A primer energiát erőművekben alakítják át villamos energiává. Az emberek többsége nem is sejti, hogy villamos energiát különböző berendezések (napelem, szélturbina, stb...) segítségével otthonukban is képesek előállítani, melyek használatával óvhatják környezetüket is.

2015-ben Magyarországon új szabályok léptek életbe az otthonteremtési támogatásokkal kapcsolatban. A Családok Otthonteremtési Kedvezménye (CSOK) olyan jelentős segítséget ad (vissza nem térítendő állami támogatás + kedvezményes hitel), melyek nagy mértékben hozzájárulhatnak ahhoz, hogy minél több család saját tulajdonú ingatlanba költözhessen(új építésű vagy használt felújítandó lakás, ház)[1].Az új építésű, valamint a felújítandó épületek tervezése során azonban érdemes azt megfontolni, hogy csak fosszilis energiákat használjunk vagy fektessünk be a megújuló energiákba is? A családi házak esetében a fosszilis energiával való fütés (földgáz, kőolaj, szén) során a nagyvárosokban legtöbben a földgázt részesítik előnyben, a megújuló energiák (nap-, szél-, geotermikus-, biomassza-, vízenergia) területén pedig egyre inkább a szoláris energia felhasználása lép elótérbe. Segítve a választást, SWOT analízissel összehasonlítjuk a földgáz és a napenergia felhasználásának erősségeit, gyengeségeit, az ezekben rejlő lehetőségeket és veszélyeket. 


\section{Magyarország napsütéses óráinak száma}

A Nap sugárzó teljesítményének a Földet elérő része mintegy 1731012 kW, ami több ezerszeresen meghaladja az emberiség energiaigényét [2].

Magyarország a $45^{\circ} 45^{\prime}$ és $48^{\circ} 35^{\prime}$ északi szélességek között fekszik, nagyjából középen az Egyenlítő és az Északi-sark között, a szoláris éghajlati felosztás szerint a mérsékelt övben. Éghajlata nagyon változékony [3]. A globális sugárzás a déli órákban a téli féléven (október - március) $250-600 \mathrm{~W} / \mathrm{m}^{2}$, a nyári félévben (április-szeptember) 600 - 1000 W/m². A szórt sugárzás 40-50\%-ot is eléri [2].

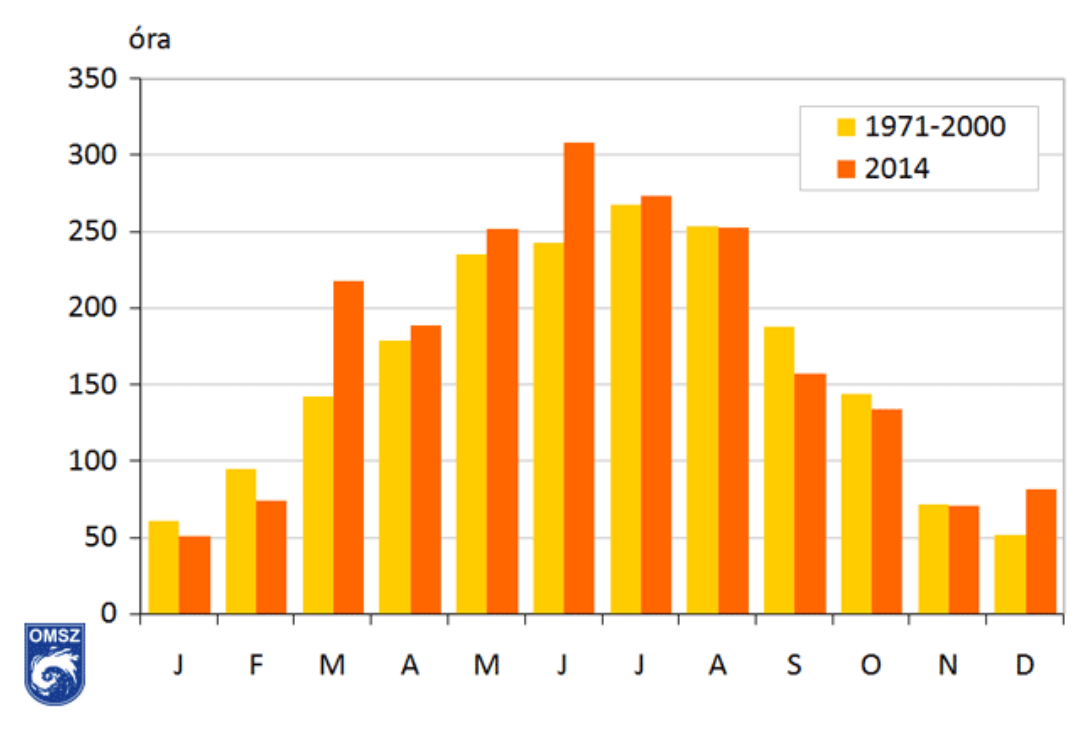

1. ábra: A napsütéses órák havi összegei 2014-ben és 1971 -2000 között

(Forrás: [4])

Hajdú - Bihar megyében a napsütéses órák száma évente átlagosan valamivel több, mint 2000 órára tehető, az évi középhőmérséklet $10^{\circ} \mathrm{C}$ közelében alakul. Az évi abszolút hőmérsékleti maximumok átlaga $33,7-34,0^{\circ} \mathrm{C}$ körüli.[5]

2014 márciusában és júniusában jelentősen megnövekedett a napsütéses órák száma, ugyanakkor2014 decemberében is jóval többet sütött a nap, mint az 1971-2000 közötti időszakban (1. ábra).

Magyarországa napsütéses órák számát tekintve igen kedvező adottságokkal rendelkezik a napenergiával működő rendszerek telepítéséhez.

\section{Magyarországon lévő földszintes családi házak illetve a háztartási kiserőművek áttekintő adatai}

A KSH 2011-es adatai alapján, Magyarországon 258500 földszintes családi ház található, amelynek nagy része fütésre fosszilis tüzelőanyagokat használ [6]. Amennyiben csak a 2 millió családi házra 
kerülne fel 2 kW-os napelemes rendszer, akkor körülbelül 8 milliárd kWh energia termelődhetne, ami kiválthatná a Paksi atomerőmű két blokkja által évente megtermelt energiamennyiséget [14].

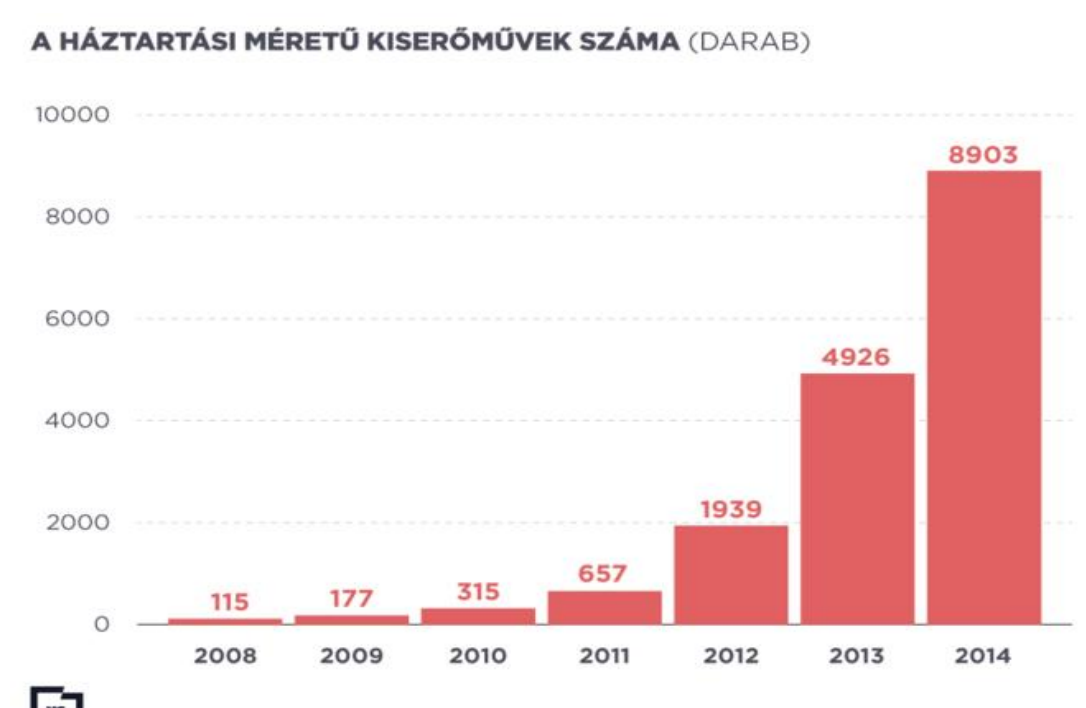

[.

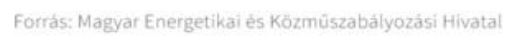

2. ábra: A háztartási méretű kiserőmúvek száma Magyarországon

(Forrás: [7])

2008-hoz képest 2014-ben jelentősen nőtt a háztartási méretű kiserőművek darabszáma (2. ábra). Míg 2008-ban csak 115 volt, addig2014-re 8903-ra darabra növekedett. A nagyarányú emelkedés ellenére a honi 2,5 millió földszintes családi házhoz képest ez még mindig nagyon csekély mértékű. A kis beruházási kedvet magyarázhatja, hogy az emberek jellemzően csak olyan projektekbe fektetnek be, amelyek kevésbé kockázatosak és kevésbé költséghatékonyak, és emellett a magyarországi támogatások sem kellő mennyiségűek. Legutóbb 2011-ben volt lakossági pályázat, de csak napkollektoros rendszerek telepítésére, melyre családonként maximum 800000 Ft-ot lehetett igénybe venni [13].

\section{A SWOT-elemzés}

Az 1960-as években a Harvard Business School fejlesztette ki a SWOT-elemzés módszerét. Segítségével leírhatóak egy eljárás, egy projekt, egy szervezet, egy ágazat stb. pillanatnyi helyzetének jellemzői. Célja, hogy összegyűjtse azokat a belső jellemzőket, amelyek erősségnek tekinthetőek, illetve azokat, amelyek gyengeségek lehetnek. Az elemzéssel pozitív és negatív külső adottságokat és tendenciákat veszélyek és lehetőségek formájában lehet meghatározni. A módszer felhasználásával felmérhetők azok a tényezők, amelyek szükségessé és lehetővé teszik egy projekt megvalósítását, illetve elősegíthetik vagy akadályozhatják a cél elérését. Vizsgálhatóak belső és külső környezeti jellemzők is [8]. 
- ERŐSSÉGEK: Olyan képesség, amely a másik eszközhöz képest kimagaslóan jobb tulajdonsággal rendelkezik.

- LEHETŐSÉGEK: Választék növekedése. Milyen új lehetőségek vannak.

- GYENGESÉGEK: Olyan képesség, amelynél van sokkal jobb képesség viszont nem alkalmazzák.

- VESZÉLYEK: Olyan tulajdonság, ami által hiba következhet be[8].

\subsection{Napenergia SWOT-elemzése}

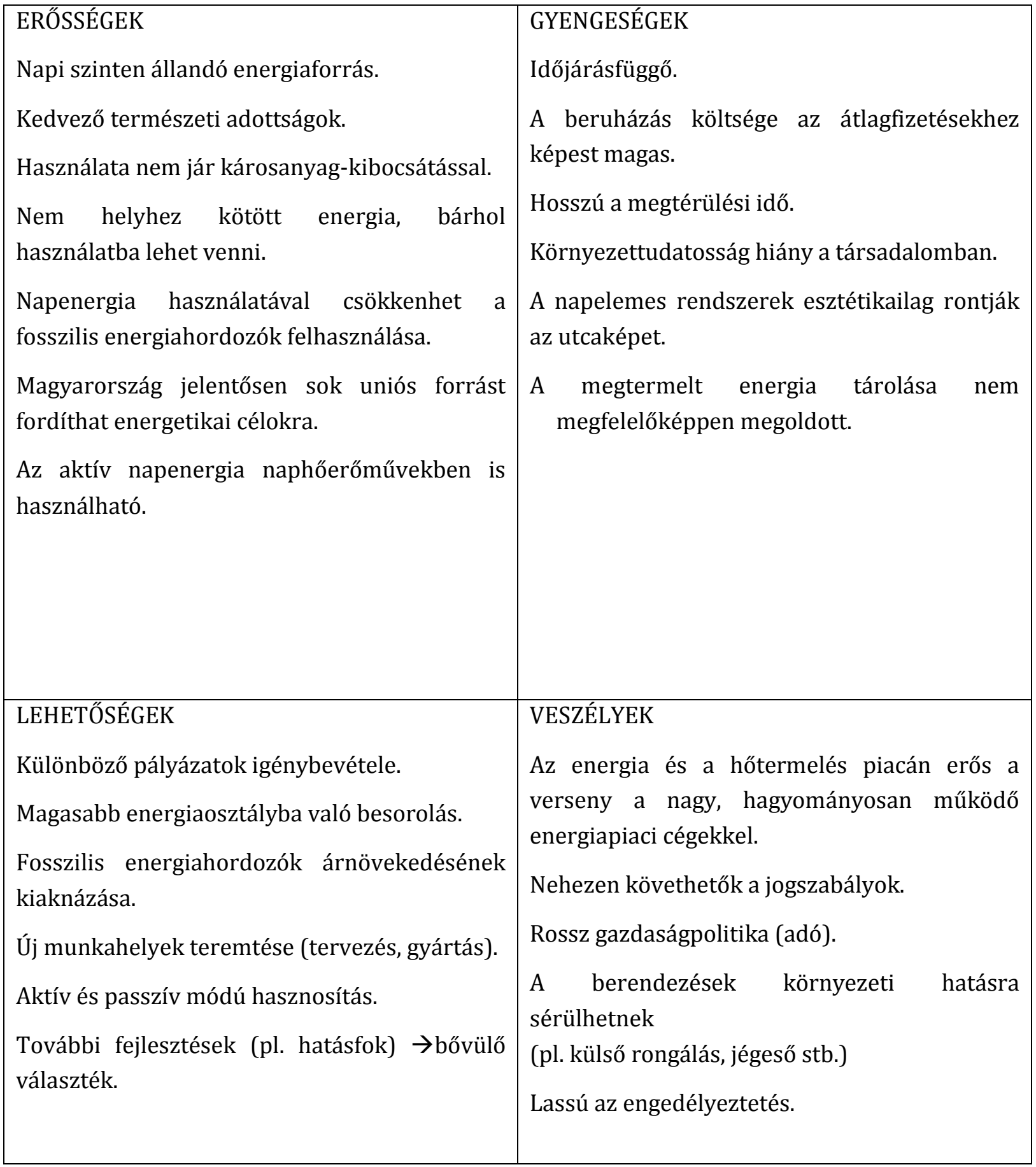




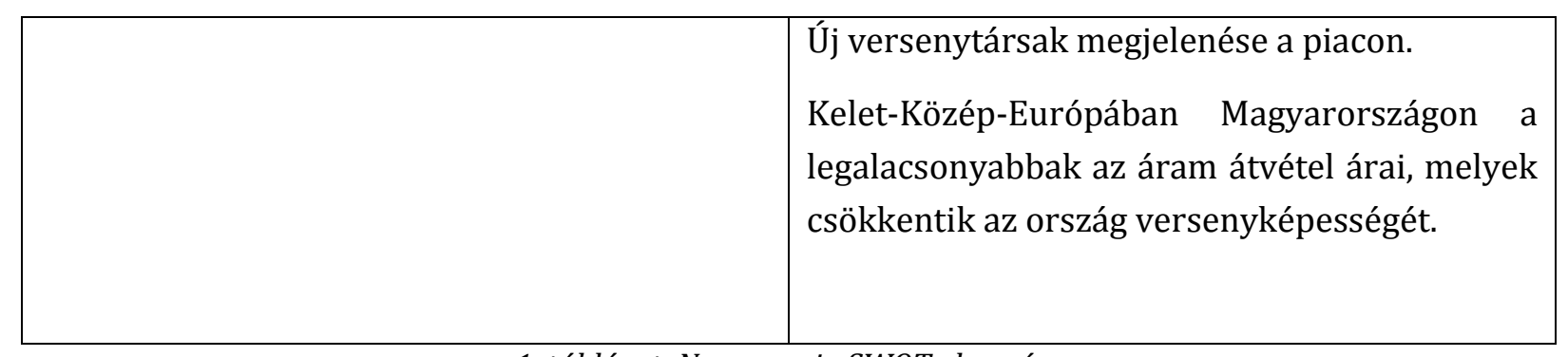

1. táblázat: Napenergia SWOT elemzése

(Forrás: [9])

\subsection{A földgáz SWOT-elemzése}

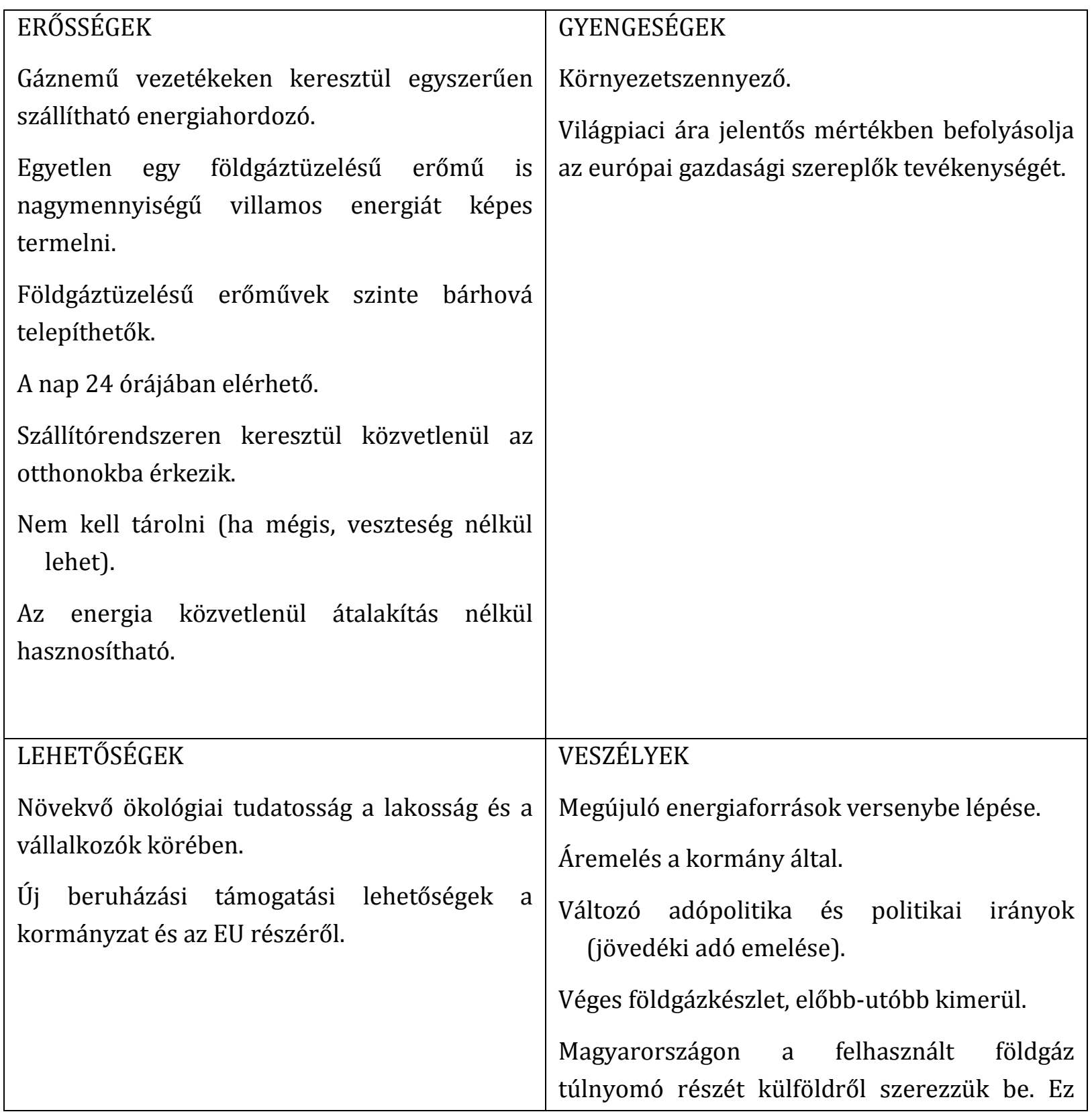




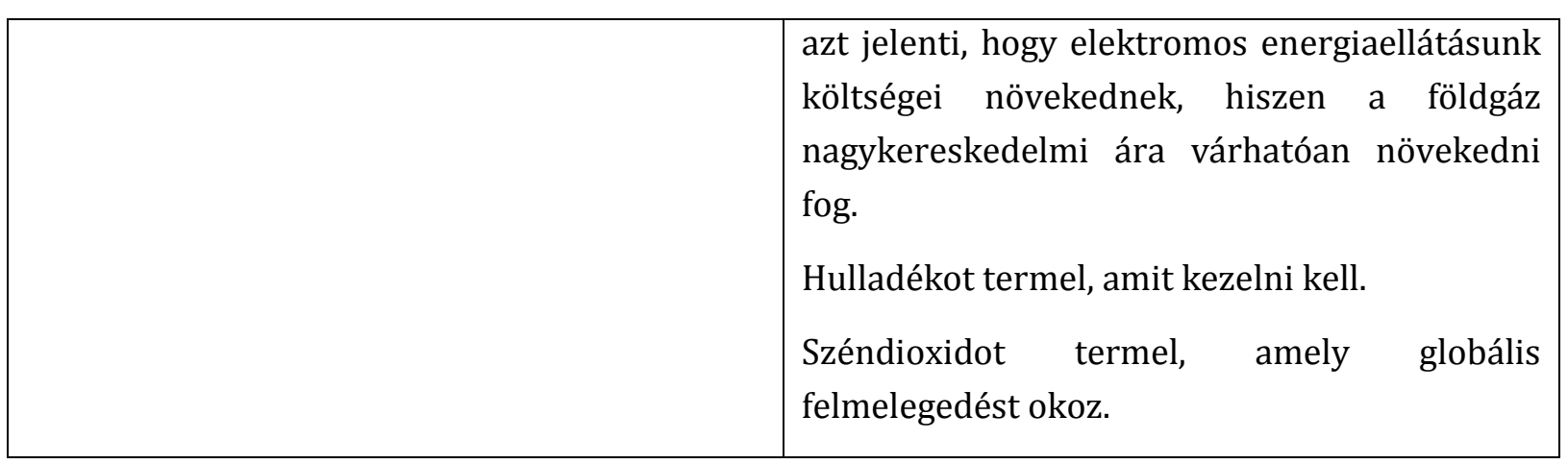

2. táblázat: Földgáz SWOT elemzése

(Forrás: [10])

\section{A vizsgált családi ház bemutatása}

A vizsgálatunkhoz kiválasztott családi ház Hajdú-Bihar megye területén, Debrecentől nagyjából 20 kilométerre fekvő Hajdúszoboszlón található. A lakóépület a város keleti részén fekszik, hasznos alapterülete $143 \mathrm{~m}^{2}$. A család villamos energiaszükségletének fedezésére 21 darab napelemet alkalmaznak. A napelemek a lakóépület szerkezetére illetve a melléképület tetőszerkezetére vannak felszerelve. A tető hajlásszöge $27^{\circ}$.

A lakásban tartósan élők száma 2 fő, évente egy hónapon keresztül 5 főre bővül. Az éves elektromos áramfogyasztás 2900 KW, amelynek a költsége 135745 Ft.

Az építtető az alábbi indokokat fogalmazta meg a napelemekbe való beruházásával kapcsolatban:

- az épület magasabb energiaosztályba való besorolhatósága,

- környezettudatosság,

- a villamos energiafogyasztásának részbeni/teljes kiváltása megújuló energiaforrások felhasználásával működő termelő berendezéssel, illetve az elszámolási időszakban keletkező többlettermelés értékesítése,

- rendelkezett a beruházáshoz szükséges tőkével.

\section{A családi ház napelemes rendszerének adatai}

A családi ház energiafogyasztása 2900kWh/év (365 nap * 24 óra * 0,33kW).

A rendszer energiahozama: $5 \mathrm{kWh}, 1250 \mathrm{kWh} / \mathrm{m}^{2}$ éves napsugárzási nyereség, 10\% éves hatásfok ( $27^{\circ}$ dőlésszög).

A panelek mérete 1,6 m², ebből következik, hogy $41 \mathrm{~m}^{2}$ tetőfelületre volt szükség.

A befektetés költségei:

\begin{tabular}{|l|l|l|}
\hline Megnevezés & Mennyiség & Ár \\
\hline Napelemek ára (Trina típusú polikristályos) teljesítménye & $21 \mathrm{db}$ & $1080000 \mathrm{Ft}$ \\
\hline
\end{tabular}




\begin{tabular}{|l|l|l|}
\hline $240 \mathrm{~W}$ & & \\
\hline $\begin{array}{l}\text { Inverter (FRONIUS IG TL 5 tip.) névleges teljesítménye 5040 } \\
\mathrm{W}\end{array}$ & $1 \mathrm{db}$ & $232500 \mathrm{Ft}$ \\
\hline Szerelési anyagok, biztonsági szerelvények & & $310000 \mathrm{Ft}$ \\
\hline Szerelési költség & & $180865 \mathrm{Ft}$ \\
\hline Összes költség + ÁFA & & $2150000 \mathrm{Ft}$ \\
\hline
\end{tabular}

3. táblázat: Napenergiás berendezés adatai

A beruházás befejezése után beépített elektromos fogyasztók:

- 1 db ARISTON 100 literes elektromos tárolós vízmelegítő, az eddig üzemelő tárolós gázvízmelegítő helyett.

- 2 db hűtő fütő klímaberendezés, 2.4 és $3 \mathrm{KW}$ teljesítményű.

A napelemes rendszer 2015. május 7-én lett üzembe helyezve. 2016. január 31-ig 2976 kW-ot termelt, ezen időszak alatt a fogyasztás $2830 \mathrm{~kW}$ volt.

\subsection{A megtérülés számításának első módszere}

Az első alkalmazott módszerünk alapján a napelemes rendszer megtérülésének kiszámításakor több tényezőt kellett figyelembe vennünk:

- a beruházás értéke(2 $150000 \mathrm{Ft}$ );

- az éves energiafelhasználás csökkentéséből származó megtakarítást (2900kw/h = 135754 Ft).

- az áramszolgáltatónak eladott energia. Az 5 kW-os napelemes rendszer megfelelő telepítéssel éves szinten kb. $5000 \mathrm{~kW} / \mathrm{h}$ villamos energiát is megtermelhet a tulajdonosának,tehát jóval többet, melyre éves szinten szükség van $(2900 \mathrm{~kW} / \mathrm{h}=135754 \mathrm{Ft})$.Az EON Energiakereskedelmi Kft-nek eladott többletenergia évente minimum $2000 \mathrm{~kW} / \mathrm{h}$. Az EON esetében a többlettermelés a fogyasztói ár $85 \%$-ával kerül elszámolásra. A termelési többletről és ennek átvételi áráról a 273/2007. Kormányrendelet alapján a felhasználó az évente egyszeri elszámoláskor értesítést kap. A túltermelt energia adóalapot képez, ami után az üzemeltetőnek adóznia kell. A családi ház tulajdonosa $\sim 40$. 000 Ft-ot kaphat évente a visszatáplált energiáért. Amennyiben számla nem kerül kibocsátásra, a „többlet” elveszett, a túltermelt energiát nem lehet a következő évre „átvinni” és „lefogyasztani”.

$$
\begin{gathered}
\text { Megtérülés }=\frac{\text { Beruházás értéke }}{\text { Éves energiafelhasználás csökkentéséből származó megtakarításunk }} \\
+ \text { Az áramszolgáltatónak eladott energia }
\end{gathered}
$$

Megtérlüés $=\frac{2150000}{135745+40000}=12,23$ év 


\subsection{A megtérülés számításának második módszere}

A második számításunkat Bánóczy és szerzőtársai által is alkalmazottak szerint készítettük el [11], nettó jelenérték (NPV) számítással. Ezzel az eljárással a projekt hasznos élettartama során történő pénzmozgások hasonlíthatók össze és ezek összegezhetők is. A nettó jelenérték egy adott kamatláb melletti diszkontált jövedelmet jelent. A számításunknál figyelembe vettük, hogy a beruházás utáni minden 10. évben egy új invertert kell vásárolni, ugyanis az inverter élettartama körülbelül ennyi időt tesz ki [12].

Egy beruházás nettó jelenértéke a megvalósítás $\mathrm{T}_{0}$ időpontjában egyenlő a beruházáshoz kapcsolódó nettó pénzáramok nettó jelenértékével:

$$
N P V=-I_{0}+\sum_{i=1}^{n}\left(R_{i}-D_{i}\right)(1+t)^{-i}+V_{n}(1+t)^{-n}
$$

ahol:

$\mathrm{n}=$ a projekt élettartama,

$\mathrm{I}_{0}=$ kezdő pénzáram T0 időpontban (a beruházás megvalósítási költsége),

$\mathrm{R}_{\mathrm{i}}=\mathrm{az}$ i. periódus működési bevétele (hozama),

$D_{i}=$ az i. Periódus működési kiadásai,

$\mathrm{R}_{\mathrm{i}}-\mathrm{Di}=\mathrm{az}$ i. periódus nettó cash flow-ja,

$\mathrm{t}=$ diszkontráta,

$\mathrm{V}_{\mathrm{n}}=$ a beruházás maradványértéke $\mathrm{T}_{\mathrm{n}}$ időpontban [15].

A beruházás akkor térül meg, ha az NPV=0-val.

\begin{tabular}{|l|l|l|l|l|l|l|}
\hline Évek & Bevétel & Kiadás & $\begin{array}{l}\text { Bevétel- } \\
\text { kiadás }\end{array}$ & $\begin{array}{l}\text { diszk. } \\
\text { faktor }\end{array}$ & $\begin{array}{l}\text { diszk. } \\
\text { hozadék }\end{array}$ & $\begin{array}{l}\text { kumulált diszk. } \\
\text { hozadék }\end{array}$ \\
\hline 0 & 0 & 2150000 & -2150000 & 1 & -2150000 & -2150000 \\
\hline 1 & 175745 & 0 & 175745 & 0,9709 & 170626,2 & -1979374 \\
\hline 2 & 175745 & 0 & 175745 & 0,9426 & 165656,5 & -1813717 \\
\hline 3 & 175745 & 0 & 175745 & 0,9151 & 160831,6 & -1652886 \\
\hline 4 & 175745 & 0 & 175745 & 0,8885 & 156147,2 & -1496739 \\
\hline 5 & 175745 & 0 & 175745 & 0,8626 & 151599,2 & -1345139 \\
\hline 6 & 175745 & 0 & 175745 & 0,8375 & 147183,7 & -1197956 \\
\hline 7 & 175745 & 0 & 175745 & 0,8131 & 142896,8 & -1055059 \\
\hline
\end{tabular}




\begin{tabular}{|l|l|l|l|l|l|l|}
\hline 8 & 175745 & 0 & 175745 & 0,7894 & 138734,7 & -916324 \\
\hline 9 & 175745 & 0 & 175745 & 0,7664 & 134693,9 & -781630 \\
\hline 10 & 175745 & 232500 & -56755 & 0,7441 & $-42231,1$ & -823861 \\
\hline 11 & 175745 & 0 & 175745 & 0,7224 & 126961,9 & -696899 \\
\hline 12 & 175745 & 0 & 175745 & 0,7014 & 123264 & -573635 \\
\hline 13 & 175745 & 0 & 175745 & 0,6810 & 119673,8 & -453962 \\
\hline 14 & 175745 & 0 & 175745 & 0,6611 & 116188,1 & -337773 \\
\hline 15 & 175745 & 0 & 175745 & 0,6419 & 112804 & -224969 \\
\hline 16 & 175745 & 0 & 175745 & 0,6232 & 109518,5 & -115451 \\
\hline 17 & 175745 & 0 & 175745 & 0,6050 & 106328,6 & $-9122,34$ \\
\hline 18 & 175745 & 0 & 175745 & 0,5874 & 103231,7 & 94109,32 \\
\hline 19 & 175745 & 0 & 175745 & 0,5703 & 100224,9 & 194334,2 \\
\hline 20 & 175745 & 232500 & -56755 & 0,5537 & $-31423,9$ & 162910,4 \\
\hline
\end{tabular}

4. táblázat: Napenergia megtérülése

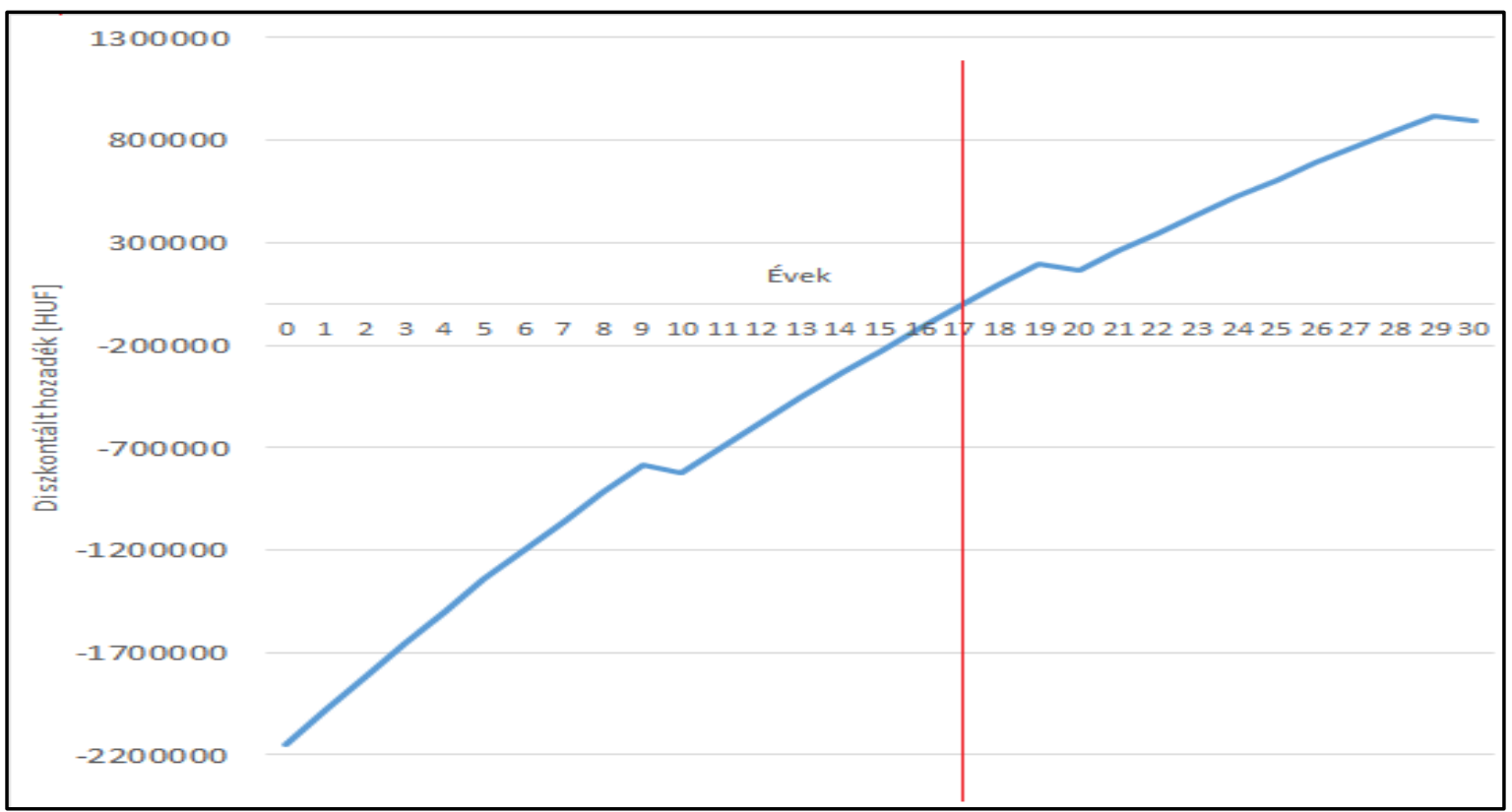

3. ábra: Napelemes rendszer megtérülésének ideje grafikonnal ábrázolva

(Forrás: Saját szerkesztés)

A második alkalmazott módszer alapján 17 év múlva fog megtérülni a vizsgált beruházás (4. táblázat, 3. ábra).10 évente törés látható, amely az inverter cseréje miatt van. 
Megállapítható, hogy a két módszer eredménye jelentősen eltér egymástól, az első esetben 12,23 év, míg a másodikban 17 év a beruházás várható megtérülési ideje. A hosszabb megtérülési időt eredményező módszer pontosabbnak tekinthető, mivel annál már az inverter cseréjének költsége is számításba lett véve.

Fontos megjegyezni, hogy az alkalmazott módszereknél nem lettek figyelembe véve plusz költségeket okozó tényezők. Tudniillik az inverter cserjén kívül még más egyéb problémák is keletkezhetnek az üzemelési idő alatt, amelyekkel a napelemes rendszert alkalmazó családi háztulajdonosnak kalkulálni kell, mivel ezek a megtérülési időt nagymértékben befolyásolhatják, például:

- nem várt kár következik be, például ha a 21 napelem közül egy vagy több darab meghibásodik, akkor cserélni kell (elromlik egy napelem, amelyből következik, hogy az egy sorba kapcsolt napelemeket), amelyek további ráfordításokat jelenthetnek az üzemeltetőnek. A napelem árak folyamatosan változnak így a most megvásárolt napelem 5-10 év múlva értékében nőni vagy csökkeni fog, ennek következményében sem lehet pontosan számolni,

- az évek elteltével nem megfelelő hatásfokkal múködnek a napelemek,

- változó energiaár miatt nem lehet pontosan számolni azzal, hogy az áramszolgáltató 5-10 év múlva mennyiért fogja visszavásárolni a fogyasztó által termelt villamos energiát.

Felmerül a kérdés, hogy van-e értelme befektetni egy olyan projektbe, amely előreláthatóan ekkora idő múlva térül csak meg, figyelembe véve azt, hogy a napelemek élettartalma várhatóan 20-25 év.

\section{7. Összefoglalás}

Kutatásunk témája a Napenergiáját hasznosító berendezésekbe való befektetés illetve megtérülés vizsgálata volt családi ház esetében. Magyarországon a családok energiaellátásra elsősorban a fosszilis energiahordozókkal működő rendszereket használják. Az ezekbe való beruházás egyszerűbb, kényelmesebb, kevesebb befektetést igényel, valamint az elszámolási rendszerük is átláthatóbb, mint a napelemeseké.

Az elvégzett kutatásunk alapján, a háztartási méretű napelemes rendszerek jóval több, mint 10 év után termelhetnek csak hozamot az üzemeltetőknek. Nagyon fontosnak tartjuk, hogy csak olyan méretű napelemes rendszert telepítsünk, amely valóban fedezi a család elektromos energiaigényét. A túlméretezett rendszerek többletenergiát termelnek, amelyeket az évi egyszeri elszámoláskor számla ellenében ugyan átvesz a szolgáltató, de az előadónak számlaképesnek kell lennie. Mindenféleképpen szorgalmaznánk Németország példáját, ahol az állam jelentős kedvezményekkel (pályázatok, hitel) ösztönzi a lakosságot arra, hogy napelemes rendszerekbe fektessenek. Magyarországon a családok számára legutóbb 2011-ben volt lakossági pályázat, amely összege 2 nap alatt kimerült [13]. 


\section{Hivatkozások}

[1] Nemzetgazdasági Minisztérium (2016), Családok Otthonteremtési Kedvezménye, In: http://www.kormany.hu/download/0/86/40000/U\%CC\%88gyfe\%CC\%81lta\%CC\%81je \%CC\%81koztato\%CC\%81honlapCSOK20150701.pdfLetöltés ideje: 2016.03.09. 14:20

[2] L. Tóth (2011), Települési In: http://www.tankonyvtar.hu/hu/tartalom/tamop412A/20100019_Telepules_energetika/ch11.htmlLetöltés ideje: 2016.03.09. 16:40

[3] OMSZ, Magyarország éghajlata- általános leírás, In: http://www.met.hu/eghajlat/magyarorszag_eghajlata/altalanos_eghajlati_jellemzes/altal anos_leiras/Letöltés ideje: 2016.03.10. 20:00

[4] OMSZ, Elmúlt évek időjárása, In: http://www.met.hu/eghajlat/magyarorszag_eghajlata/eghajlati_visszatekinto/elmult_eve k_idojarasa/Letöltés ideje: 2016.03.10. 20:20

[5] Általános földrajzi jellemzők, In:http://portal.debrecen.hu/gazdasag/koncepciok/varosfejlesztesi/varosfejlesztes2007_ koncepciok.html?page=1Letöltés ideje: 2016.03.12. 15:20

[6] KSH, In:http://www.ksh.hu/docs/hun/xftp/idoszaki/nepsz2011/nepsz_06_2011.pdfLetöltés ideje: 2016.03.14. 19:15

[7] Akart volna féláron napelemet? Az államé less, In: http://vs.hu/gazdasag/osszes/akartvolna-felaron-napelemet-az-allame-lesz-0702\#!s0 Letöltés ideje: 2016.03.14. 21:41

[8] T. Jenei (2012), Geotermikus projektek SWOT - analízise = SWOT analysis of geothermalprojects, In: Pokorádi László (szerk.) Műszaki Tudomány az Észak-kelet Magyarországi Régióban, konferencia előadásai : Szolnok, 2012. május 10. 648 p. Konferencia helye, ideje: Szolnok, Magyarország, 2012.05.10 Debrecen: MTA Debreceni Akadémiai Bizottság,.pp. 277-283. (ISBN:978-963-7064-28-9)

[9] I. Farkas (2003), Napenergia a mezőgazdaságban

[10] Energiaforrások, In:http://www.energiakaland.hu/energiavilag/energiaforrasok/foldgazLetöltés ideje: 2016.03.17. 21:34

[11] E. Bánóczy, P. T. Szemes, P. Korondi (2014), Simulation of building renovation's returninenergy plus, In: Environmental Engineering and Management Journal 13:(11) pp. 2743-2748.

[12] Napelem inverterek, In: http://napeleminverter.hu/Letöltés ideje: 2016.03.16. 22:09 
[13] ÚSZT Lakossági napkollektoros pályázat, In: http://www.naplopo.hu/miertnapenergia/allami-tamogatas-palyazatok/lakossagi-palyazatok/124-lakossagipalyazatok-archiv/14-uszt-zbr-nap-2011Letöltés ideje: 2016.03.20. 23:11

[14] MTTSZ Észrevétel, In: https://www.palyazat.gov.hu/node/56574Letöltés ideje: 2016.03.20. 14:21

[15] J. Pucsek (2013), Pénzügyi és számviteli kontrolling, In: http://www.tankonyvtar.hu/hu/tartalom/tamop412A/0007_e7_penzugyi_es_szamviteli_ kontrolling_scorm/netto_jelenertek_npv_sBTMLDyvGqy1Dp5a.htmlLetöltés ideje: 2016.03.16. 17:14 